\title{
IMPLEMENTASI GRAPH COLORING DALAM PEMETAAN KECAMATAN DI KABUPATEN KEDIRI
}

\author{
Risky Aswi Ramadhani \\ Fakultas Teknik, Program Studi Teknik Informatika \\ Universitas PGRI Kediri \\ Email: risky_aswi@unpKediri.ac.id
}

\begin{abstract}
ABSTRAK
Kabupaten Kediri adalah kabupaten yang cukup berkembang, bahkan saat ini perkembangan kabupaten Kediri tergolong pesat. Kabupaten Kediri memiliki 26 kecamatan, kecamatan tersebut saling terhubung. Hubunngan antar kecamatan ini yang akan mempengaruhi perkembanganya. Pada saat ini kabupaten Kediri melakukan pembangunan yang pesat. Pembangunan kabupaten Kediri dilaksanakan pada kecamatan yang memiliki letak yang strategis, mudah diakses oleh kecamatan disekitarnya. Kecamatan yang memliki degree banyak maka kecamatan tersebut bisa dijadikan proritas pengembngan kabupaten Kediri. Karena kecamatan yang memiliki degree banyak pasti sangat mudah diakses oleh kecamatan disekitarnya. Dengan memanfaatkan metode graph coloring jumlah vertek dan edgee yang ada pemerintah kabupaten Kediri dapat mengetahui posisi setiap kecamatan dengan mudah dan mengetahui ke strategisan setiap kecamatan. Setelah dilakukan pencarian degree terbanyak maka pemerintah kabupaten Kediri dapat melakukan pembangunan pada kecamatan tersebut. Dengan melakukan pembangunan pada kecamatan yang memiliki degree terbanyak (strategis), pembangunan pusat ekonomi, kesehatan dan pendidikan akan dilakukan pada kecamatan tersebut akan berimbas pada kecamatan disekitarnya, selain itu kecamatan yang memiliki degree banyak sangat mudah diakses oleh kecamatan disekitarnya.
\end{abstract}

Kata kunci: edgee, graph coloring, pemetaan, vertex.

\section{ABSTRACT}

Kediri is a district that is developing, even now relatively rapid development of the district keduri. Kediri has 26 districts, the districts are connected. Hubunngan between these districts which will affect the current district perkemabanganya.Pada Kediri perform rapid development. Kediri district development carried out at district that has a strategic location, easily accessible by kecapamatan surroundings. Districts that discount the degree many districts can be used as a priority pengembngan Kediri district. Because the district which has many degree must be very accessible to the surrounding districts. By utilizing the method graph coloring number edgee existing vertex and district governments Kediri can know the position of each sub-district with ease and knowing strategisan setian district. After searching the highest degree. Kediri district government can do development in these districts. By doing construction in the district that has the highest degree (ideally), building the economy, health and education will be conducted in these districts will impact on the surrounding districts, in addition to the degree many districts that have very easily accessible by the surrounding districts

Keywords: edgee, graph coloring, mapping, vertex.

\section{PENDAHULUAN}

Kediri merupakan kabupaten yang cukup berkembang, untuk mendukung perkembangan kabupaten Kediri diperlukan persiapan yang matang. Persiapan tersebut bisa dimulai dari SDM, Peralatan, maupun analisa wilayah. Pada penelitian ini akan dibahas graph coloring, graph coloring digunakan sebagai bahan untuk mengembangkankan kabupaten Kediri .

Proses transformasi kota menjadi metropolitan ini umumnya diawali oleh bergabungnya kota-kota yang berdekatan[1]. Dengan membangun pusat kecamatan dari beberapa kumpulan kecamatan diharapakan kemajuan setiap kecamatan hampir sama. Dengan memilih salah satu kota yang paling strategis untuk pembengmbangan kecamatan, maka kecamatan disekitarnya akan melakukan trasnsaksi jual beli di kecamatan yang memiliki degree yang paling banyak.

Teori graph merupakan topik yang banyak mendapat perhatian saat ini, karena model-model yang ada pada teori graph berguna untuk aplikasi yang luas[2]. graph coloring sendiri terdiri dari vertex dan edgee. Edgee bisa terbentuk apabila ada beberpa vertex saling terhubung. Pada penelitian ini yang akan 
dijadikan vertex adalah kecamatan dikabupaten Kediri. Setiap kecamatan di kabupaten Kediri saling berbatasan dengan kecamatan lain. Perbatasan ini yang akan dijadikan dasar pembentukan edgee.

Apabila dilihat dari jumlah kecamatan yang ada di kabupaten Kediri jumlah vertex yang akan digunakan adalah 26 vertex, vertex digambarkan sebagai kecamatan, jika antara kecamatan saling berbatasan maka ada 2 vertex yang bertemu, hal seperti ini disebut edgee.

Kota yang memiliki edgge paling besar adalah kecamatan yang strategis, yang dimaksud strategis adalah, kecamatan ini terhubung dengan bnyak kecamatan di sekitarnya. Kecamatan yang memiliki degrre yang paing banyak menjadi central kabupaten. Pengembangan kabupaten seharusnya terpusat pad kecamatan tersebut.

Kecamatan yang maju saling bergantung ke kecamatan yang lain, kecamatan yang memiliki degree sedikit untuk pengembanganya pasti sulit. harapan membangun kecamatan yang memiliki degree banyak pemerintah dapat memusatkan pembangunan pusat ekonomi, pendidikan kesehatan pada kecamatan tersebut dan kecamatan disekitarnya mudah mengakses, selain itu kemajuan kecamatan yang memiliki degree banyak akan berimbas pada kecamatan disekitarnya.

\section{METODOLOGI PENELITIAN}

Metode Penelitian adalah urutan meneliti, berikut ini adalah flowchart metode penelitian yang akan digunakan. Penelitian ini dilakukan untuk mencari degree antar kecamatan di kabupaten Kediri. Untuk lebih jelasnya silahkan lihat gambar 3 .

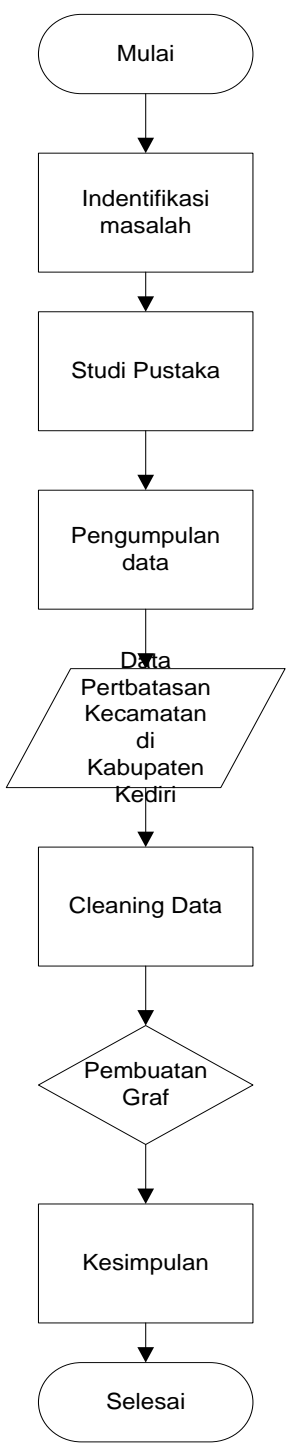

Gambar 3. Bagan Alur Penelitian 
Gambar 3. Menjelaskan bagaiaman langkah-langkah penelitian yang dilakukan pada penelitian ini terdapat 8 langkah yaitu:

1) Indentifikasi masalah: permasalahan yang didapatkan pada penelitian ini adalah bagaimana menentukan kecamatan yang paling strategis di kabupaten Kediri .

2) Studi Pustaka: Pencarian sumber refrensi baik itu dari jurnal, mupun buku yang berkaitan dengan graph coloring.

3) Pengumpulan data: data perbatasan setiap akecamatan akan dicatat.

4) Data kecamatan dikabupaten Kediri adalah proses input ke nodexl.

5) Cleaning data: saat pengumpulan data biasanya terjadi input data ganda, agar hasil akurat maka perlu dilakukan cek ulang dan dilakukan cleaning.

6) Pembuatan graph dari kecamatan di kabupaten Kediri yang saling berkaitan.

7) Penarikan kesimpulan sehingga hasil dari penelitian ini dapat digunakan sebgai dasar pengembangan kecamatan di kabupaten Kediri.

\section{HASIL DAN PEMBAHASAN}

Kebutuhan masyarakat akan penentuan atau pencarian letak suatu bangunan atau tempat dengan korelasi yang ada antara suatu tempat dengan tempat yang lain dan dengan kemajuan teknologi terutama pada visualisasi. Sehingga masyarakat sekarang cenderung mengerti atau mengatahui suatu lokasi berdasarkan apa yang pernah mereka perkirakan atau apa yang dilihat sebelumnya. Oleh karena itu, diperlukan suatu penyajian peta yang menarik dan mudah dipahami dengan mengandung kaidah kartografi pada setiap objek bangunan yang cenderung lebih disukai dibanding dengan pembedaan kategori nominal, terutama bagi masyarakat awam dalam membaca informasi-informasi pada peta[3].

Pada Penelitian ini akan dibahas bagaimana membuat graph coloring dari sebuah peta, peta yang digunakan adalah peta kabupaten Kediri. Graph coloring digunakan untuk melihat perbatasan antara peta yang saling terhubung. Berikut ini adalah peta kabupaten Kediri.

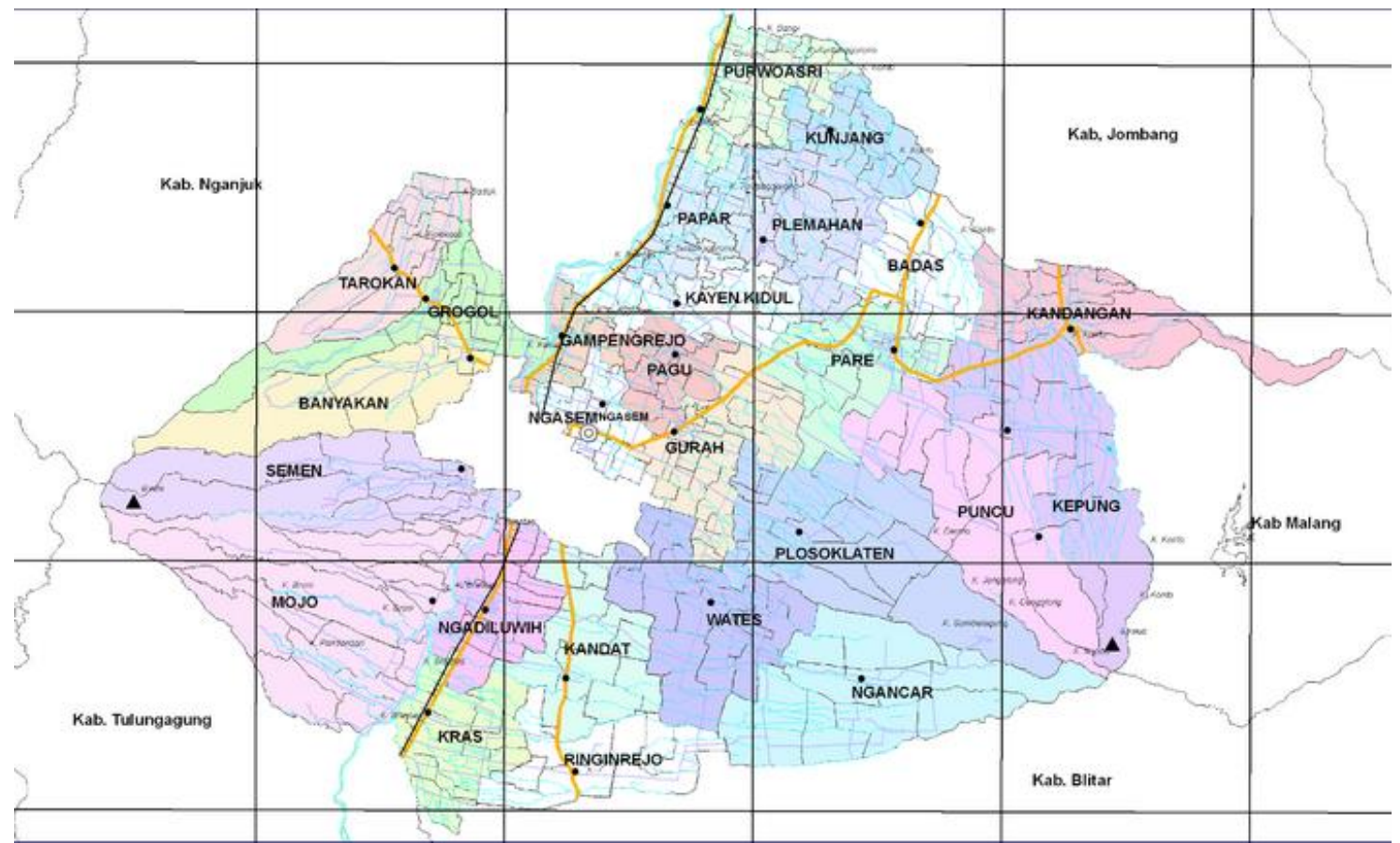

Gambar 4. Peta Kabupaten Kediri

Sumber: Pemerintah kabupaten Kediri

Gambar 3 adalah peta kabupaten Kediri, pada peta kabupaten Kediri gambar ini digunakan sebagai rujukan untuk melakukan pengambilan data perbatasan anatar kecamatan di kabupaten Kediri. Setiap kecamatan yang saling terhubungang akan ditandai sebagai edge.

Secara informal, suatu graph adalah himpunan benda-benda yang disebut simpul (vertex atau node) yang terhubung oleh sisi (edge) atau busur (arc). Biasanya graph digambarkan sebagai kumpulan titiktitik (melambangkan simpul) yang dihubungkan oleh garis-garis (melambangkan sisi) atau garis berpanah (melambangkan busur). Suatu sisi dapat menghubungkan suatu simpul dengan simpul yang sama. Sisi 
yang demikian dinamakan gelang (loop). Secara matematis, graph $\mathrm{G}$ didefinisikan sebagai pasangan himpunan $(\mathrm{V}, \mathrm{E})$, yang dalam hal ini, $\mathrm{V}$ adalah himpunan tidak kosong dari simpul-simpul (vertices atau node). Dan E adalah himpunan sisi (edges atau arcs) yang menghubungkan sepasang simpul[4].

Edges menggambarkan bagaiamana setiap kecamatan di kabupaten Kediri saling terhubung, misalnya saja kecamatan Ngadiluwih berbatasan langsung dengan kecamatan Kras. Pada bagian ini digunakan untuk menghubungkan anatara kecamatan Ngadiluwih dan Kras, untuk lebih jelas silahkan lihat pada gambar 5 dibawah ini.

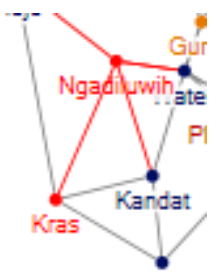

\section{Gambar 5. Edges Kecamatan Ngadiluwih Dan Kecamatan Kras}

\subsection{Degree}

Setiap Kecamatan di Kabupaten Kediri memiliki central, kecamatan yang memiliki degree terbanyak diaganggap sebgai kecamatan yang paling strategis, degree merupakan jumlah link yang menghubungkan suatu node dengan node lain[5]. Sentral adalah diamana kecamatan tersebut dapat terhubung dengan banyak kecamatan pada bagian ini kecamatan yang diangkat adalah kecamatan wates, kecamatan wates menjadi sentral karena terhubung dengan kecamatan Ngadiluwih, Kras, Plosokaten, Gurah, dan Ngancar. Untuk lebih jelasnya bisa dilihat pada gambar 6.

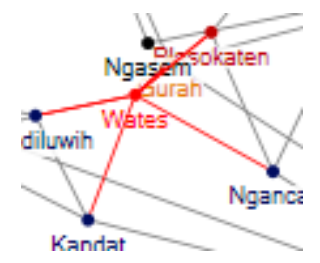

\section{Gambar 6. Degree Kecamatan Wates}

Setiap Kecamatan memiliki degree yang berbeda, berikut ini adalah daftar 5 kecamatan dengan degree paling tinggi.

Tabel 1. Daftar Degree Kabupaten Kediri

\begin{tabular}{ccc}
\hline No & Nama Kota & Degree \\
\hline 1 & Pare & 7 \\
2 & Pagu & 6 \\
3 & Gurah & 5 \\
4 & Gampeng Rejo & 5 \\
5 & Wates & 5 \\
\hline
\end{tabular}

Tabel 1 menjelaskan bahwa kecamatan pare memiliki letak paling strategis degree yang didapatkan adalah 7, Kecamatan pagu memiiliki 6 degree.

\subsection{Graph Coloring}

Graph Coloring adalah pemberian warna terhadap vertex-vertex graph di mana 2 buah vertexyang berdampingan tidak boleh mempunyai warna yang sama. Selain itu Graph coloring meruakan solusi untuk pemecahan masalah-masalah yang berhubungan dengan link antar node[6].

Bilangan kromatis dari $\mathrm{G}=\mathrm{K}(\mathrm{G})$ adalah jumlah minimum warna yang dibutuhkan. Algoritma yang dapat digunakan untuk mendapatkan bilangan kromatis dari sebuah graph adalah algoritma WelchPowell. 
Adapun langkah-langkahnya adalah:

1) Urutkan vertex-vertex berdasarkan derajatnya.Dari besar ke kecil.

2) Warnai.

Pada Penelitian ini Graph Coloring akan digunakan untuk mengetahui letak kecamatan kecamatan saling terhubung. Kecamatan yang memiliki jaringan yang banyak yang meiliki degree yang banyak adalah kecamatan yang memilikiletak paling strategis, kecamatan yang memiliki letak paling strategis akan dibangun dan dijadikan pusat ekonomi untuk beberapa kecamatan disekitarnya. Pada gambar 7 akan dijelaskan hibungan atar kecamatan, hubungan antar kecamatan ini dilihat dari perbatasan wilayah.

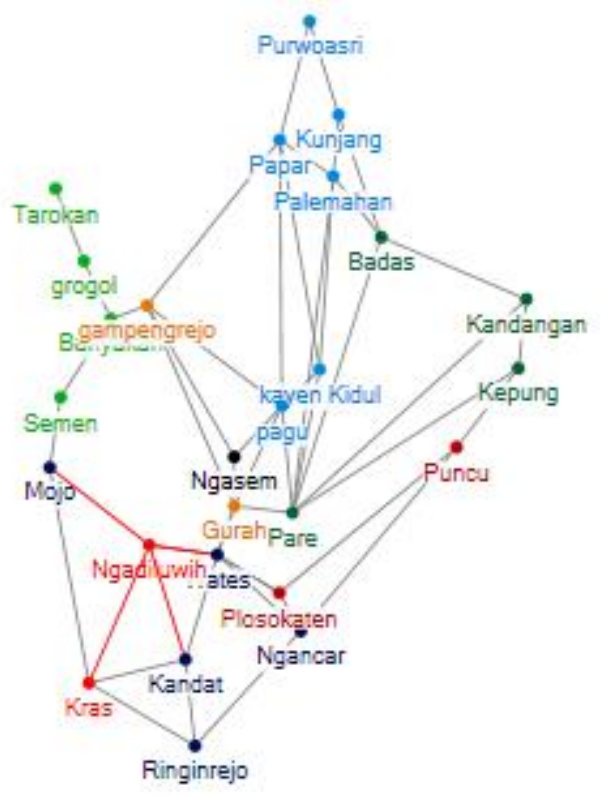

Gambar 7. Graph Coloring Kabupaten Kediri

Graph Coloring yang ditampilkan gambar 7 terbagi menjadi tujuh warna yaitu

1) Hijau: Tarokan, Grogol, Banyakan, Semen Biru.

2) Biru Muda: Purwosari, Kunjang, Papar, Palemahan, Kayen Kidul, Pagu.

3) Hijau Tua: Badas, Kandangan, Kepung.

4) Merah: Ngadiluwih, Kras.

5) Merah Hati: Plosokaten, Puncu.

6) Hitam: Wates,Kandat, Ringirejo, Ngase.

7) Hijau Tua: Pare.

\section{KESIMPULAN}

Dari hasil penelitian berupa pewarnaan grap (graph coloring) pada peta Kabupaten Kediri dapat diperoleh beberapa keseimpulan sebagai berikut:

1) Jumlah vertex (Kecamatan) yang terdapat di peta Kabupaten Kediri berjumlah 26.

2) Kecamatan Pare memiliki edgee yang paling banyak yaitu 7 edgee.

Dengan memanfaatkan graph coloring maka pengembangan Kecamatan akan lebih mudah karena pihak-pihak yang terkait mengetahui kecamatan yang paling strategis. Kecamatan yang paling strategis adalah kecamatan yang memiliki edge paling banyak.

\section{DAFTAR PUSTAKA}

[1] Winarso, Haryo 'et al.'. 2006 "Metropolitan di Indonesia:Kenyataan dan Tantangan dalam PenataanRuang,", Direktorat Jenderal Penataan Ruang, Departemen Pekerjaan Umum”.

[2] Hutabarat, Fisi. 2009. "Implementasi Graph Coloring Dalam Pemetaan Daerah Kabupaten Serdang Bedagai". Medan.

[3] Kartanegara, Uman, 2013.'Peninjauan Secara Kartografis Dalam Pembuatan Peta Kampus Universitas Diponegoro". 
[4] Lyanda, Vivi, 2012 "Pemanfaatan Algoritma Sequential Search dalam Pewarnaan Graph untuk Alokasi Memori Komputer", Bandung

[5] Aini, Viva. 2014." Analisis Pada Peringkat Top Brand Menggunakan Jejaring Sosial Percakapan Dengan Social Network Analysis ( Studi Kasus Pada Smartphone Samsung, Blackberry, Nokia, Iphone Di Indonesia)". Universitas Telkom

[6] Barenboim, Leonid. 2013."Distributed Graph Coloring: Fundamentals and Recent Developments". Ben-Gurion University of the Negev. 